\title{
Application of the Anammox Process for Treatment of Liquid Phase Digestate
}

\author{
Joanna Majtacz, Dominika Grubba * and Krzysztof Czerwionka \\ Faculty of Civil and Environmental Engineering, Gdansk University of Technology, Narutowicza Street 11/12, \\ 80-233 Gdansk, Poland; joamajta@pg.edu.pl (J.M.); kczer@pg.edu.pl (K.C.) \\ * Correspondence: dominika.grubba@pg.edu.pl
}

Received: 11 September 2020; Accepted: 14 October 2020; Published: 22 October 2020

check for updates

\begin{abstract}
The liquid phase of the digestate (LPD) contains a relatively high concentration of nitrogen, with total ammonium nitrogen being the dominant form of nitrogen, as well as other essential nutrients such as phosphorus and potassium. Consequently, it must be treated before it is released into the environment. However, there are no reports of co-purification of LPD in the anammox process in sequencing batch reactor with granular sludge, which is a novelty for the presented research. The main objective of this paper is to assess the possibility of nitrogen removal in the anammox process with LPD from biogas plants conducting the co-fermentation process along with the participation of agricultural products (cattle slurry). This publication presents the research results of the efficiency of the anammox process, accounting for the effect of dissolved organic matter. The conducted experiments revealed the potential of LPD purification, which co-ferments waste activated sludge and bovine slurry for the anammox process. In the reactor ammonium utilization rate (AUR) process with LPD addition increased from $2.3 \mathrm{mg} \mathrm{N} /(\mathrm{g}$ VSS.h) with $0.5 \%$ LPD addition to $8.5 \mathrm{mg} \mathrm{N} /$ (g VSS.h) with 7.5\% LPD addition. SAA in the reactor with LPD addition increased from $5.3 \mathrm{mg} \mathrm{N} /(\mathrm{g}$ VSS.h) with $0.5 \%$ LPD addition to $18.5 \mathrm{mg} \mathrm{N} /(\mathrm{g}$ VSS.h) with 4 and $5 \%$ LPD addition. With the addition of 7.5\% LPD, SAA dropped to a value of $18.1 \mathrm{mg} \mathrm{N} /(\mathrm{g}$ VSS.h) in the LPD reactor.
\end{abstract}

Keywords: liquid phase of the digestate; biogas production; anammox; deammonification; co-fermentation

\section{Introduction}

The anammox process is the biological process of ammonium nitrogen $\left(\mathrm{NH}_{4}-\mathrm{N}\right)$ oxidation under anaerobic conditions to gaseous nitrogen $\left(\mathrm{N}_{2}\right)$, where the electron acceptor is nitrite nitrogen $\left(\mathrm{NO}_{2}-\mathrm{N}\right)$, and the bacteria responsible for this process are anaerobic ammonia oxidizing bacteria (AAOB). Until now, the anammox process has been successfully used to treat wastewater with a high $\mathrm{NH}_{4}-\mathrm{N}$ content [1], such as leachate from landfills [2] or wastewater from pig farming [3].

The efficiency of the anammox process is influenced by many factors such as temperature, $\mathrm{pH}$, the method of aeration, and the $\mathrm{C} / \mathrm{N}$ ratio. Higher concentrations of chemical oxygen demand (COD) can lead to denitrification, in which the remaining nitrate nitrogen $\left(\mathrm{NO}_{3}-\mathrm{N}\right)$ can be converted to gaseous nitrogen $\left(\mathrm{N}_{2}\right)$. However, excessive COD concentrations increase the proliferation of heterotrophic bacteria that compete for $\mathrm{NO}_{2}-\mathrm{N}$ with $\mathrm{AAOB}$ [4].

It has been shown that with a high enough concentration of sludge and increasing the rate of influent $\mathrm{COD} / \mathrm{N}$, anammox can coexist with some heterotrophic bacteria. Literature describes a mixed system based on anammox, in which denitrification consumes $\mathrm{COD}$, anammox produces $\mathrm{NO}_{3}-\mathrm{N}$, and in the meantime provides $\mathrm{NO}_{2}-\mathrm{N}$ for anammox $[5,6]$. However, the rapid growth of denitrifying bacteria and cell growth is the main threat [7]. It is necessary to ensure appropriate conditions for carrying out both processes simultaneously, which is a challenge. 
The research of Pijuan et al. [8] indicated that the presence of a denitrifying community in the biocenosis carry out the anammox process. This community was able to absorb COD using $\mathrm{NO}_{3}-\mathrm{N}$ and $\mathrm{NO}_{2}-\mathrm{N}$ as electron acceptors. The activity of anammox was not suppressed by the addition of $\mathrm{COD}$, as the presence of COD did not result in an increase in $\mathrm{NH}_{4}-\mathrm{N}$ concentration at the end of the tests. The long-term addition of COD resulted in a decrease in anammox activity and a shift in the microbial community, with a decrease in the anammox fraction. Despite this, the anammox process was never lost and was fully recovered after the COD addition was stopped.

Moreover, a study by Qin et al. [9] also showed that a higher concentration of organic compounds (glucose) in the reactor inhibits the sludge's anammox activity and reduces the rate of $\mathrm{NH}_{4}-\mathrm{N}$ removal. However, when the $\mathrm{NO}_{2}-\mathrm{N}$ substrate was sufficient, and the glucose concentration was low, the inhibition of anammox activity was slowed. In the study by Chen et al. [10], when COD concentration in the feed was lower than $99.7 \mathrm{mg} / \mathrm{dm}^{3}$, nitrogen removal could be increased by the combination of denitrification and anammox. Increased COD negatively affects the activity of anammox with almost complete inhibition at COD concentration of $284.1 \mathrm{mg} / \mathrm{dm}^{3}$. However, the process was recovered by changing the $\mathrm{COD} / \mathrm{TN}$ ratio from 2.33 to 1.25 after adding the $\mathrm{NO}_{2}-\mathrm{N}$ feed. Until now, research was based mainly on the $\mathrm{C} / \mathrm{N}$ effect in the anammox process [11-13], not strictly the influence of $\mathrm{COD}$ concentration on $\mathrm{NH}_{4}-\mathrm{N}$ oxidation at constant $\mathrm{C} / \mathrm{N}$.

The digestate is a by-product of anaerobic digestion of biodegradable materials in biogas plants [14]. It is black in color due to the content of sulphides and humic substances. It can be divided into a solid and liquid phase [15]. The solid fraction can be incinerated, composted or used to fertilize agricultural crops. It is important to reduce hydration in the latter case, as it lowers the cost of transport thus enabling processing in greater distances from biogas plants and contributing to reduced negative effects of "over-fertilization". The liquid phase of the digestate (LPD) contains a relatively high concentration of nitrogen, with total ammonium nitrogen being the dominant form, as well as other essential nutrients such as phosphorus and potassium [16-18]. Consequently, it must be treated before it is discharged into the environment.

The main method of managing LPD is the direct application to agricultural land as fertilizer, however in EU countries, the Nitrates Directive (91/676/EEC) protects land and surface waters from nitrate contamination by limiting the amount of LPD that can be applied to soil [19].

There are also solutions that reintroduce LPD into an anaerobic digestion chamber [20]. In some cases, LPD is treated as wastewater when its nutrients cannot be effectively used in the environment [15]. This increases the nitrogenous load in the wastewater treatment plant, which contributes to higher aeration costs. However, there are no reports of co-purification of LPD in the process of anaerobic oxidation of ammonium nitrogen $\left(\mathrm{NH}_{4}-\mathrm{N}\right)$-anammox in sequencing batch reactor (SBR) with granular sludge, which is a novelty of this research. Due to the fact that LPDs are characterized by a relatively high COD content after the methane fermentation process, their co-purification in the anammox process seems to be a challenge.

Previous experiments have shown the potential of LPD in the deammonification process [21]. However, the proportion of LPD in the feed solution should be determined individually for each type of substrate after previous COD concentrations are analyzed. Stable deammonification efficiency was obtained for the $\mathrm{C} / \mathrm{N}$ ratio of 1:1. It was decided to check the influence of LPD from the biogas plant on the anammox process itself, which is a component of the deammonification process.

The main objective of the presented research is to assess the possibility of nitrogen removal in the anammox process with LPD from biogas plants conducting the co-fermentation process with agricultural products (cattle slurry). The publication presents the the research results on the efficiency of the anammox process, taking into account the effect of the dissolved organic matter fraction. For this reason, tests with the addition of sodium acetate (i.e., a fully soluble and easily biodegradable organic compound) are the benchmark. 


\section{Materials and Methods}

\subsection{Laboratory Setup}

The inoculated biomass originated from a full-scale side-stream deammonification system in Plettenberg, Germany.

The laboratory scale system used in this study consisted of one $10 \mathrm{dm}^{3}$ SBR in the deammonification mode and three batch reactors in the anammox mode laid out according to the scheme in Figure 1. The SBR was equipped with a thermostatic jacket maintaining a constant temperature in the range of -35 to $+200{ }^{\circ} \mathrm{C}$ with an accuracy of $\pm 0.1{ }^{\circ} \mathrm{C}$. The main reactor metered service probes were placed to measure pH (Endress + Hauser EH CPS 471D-7211, Switzerland) and measure dissolved oxygen (Endress + Hauser COS22D-10P3/O, Germany).

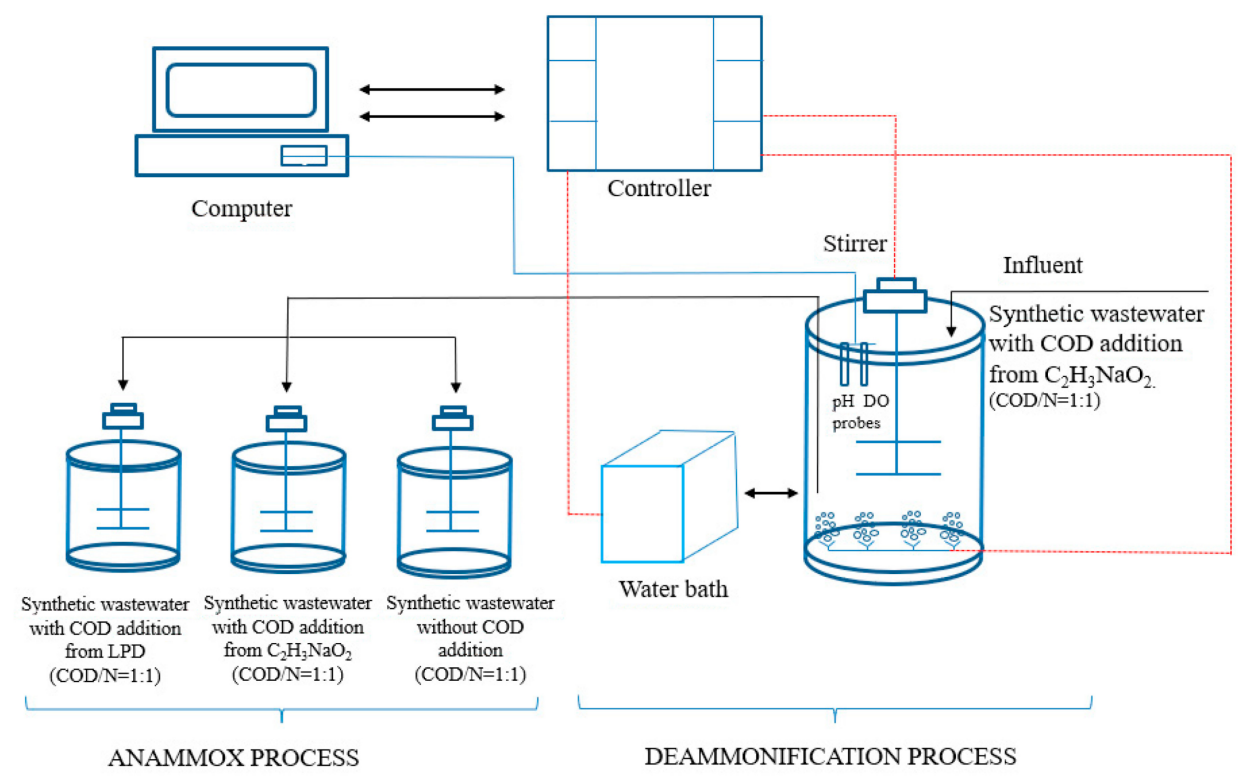

Figure 1. Scheme of the laboratory system.

All measured data from the SBR was transmitted to the programmable logic controller (PLC), which were used for control and regulation. Measurement data was sent to an application called Intouch'a.

\subsection{Operational Conditions}

(a) The Main Reactor SBR in the Deammonification Mode

The granular sludge was adapted to the deammonification process for 90 days in the SBR. During the entire test period, the SBR was operated at a constant temperature of $30 \pm 1{ }^{\circ} \mathrm{C}$. The $\mathrm{pH}$ was controlled in the range of 7.5-7.8 by the automatic addition of $4 \mathrm{M}$ sodium hydroxide $(\mathrm{NaOH})$. The concentration of dissolved oxygen (DO) in SBR was maintained at the level of $0.7 \pm 1 \mathrm{mg} / \mathrm{dm}^{3}$. Synthetic wastewater was used to supply SBR prepared according to Dapena-Mora et al. [22], but with the addition of COD (in the form of sodium acetate- $\mathrm{C}_{2} \mathrm{H}_{3} \mathrm{NaO}_{2}$ ). After each batch reactor's test, a 14-day adaptation to increase COD initial concentrations (in the form of $\mathrm{C}_{2} \mathrm{H}_{3} \mathrm{NaO}_{2}$ ) was performed in SBR according to Table 1. 
Table 1. Characteristics of tests.

\begin{tabular}{|c|c|c|c|c|c|c|c|c|c|c|c|c|c|c|}
\hline \multirow{3}{*}{ Day } & \multirow{2}{*}{\multicolumn{3}{|c|}{ SBR in Deammonification Mode }} & \multicolumn{11}{|c|}{ Batch Reactors } \\
\hline & & & & \multirow{2}{*}{ 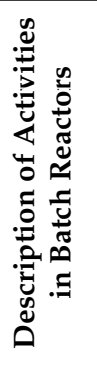 } & \multicolumn{5}{|c|}{ R1 (with COD from LPD) } & \multicolumn{3}{|c|}{$\begin{array}{l}\mathrm{R} 2 \text { (with COD from } \\
\qquad \mathrm{C}_{2} \mathrm{H}_{3} \mathrm{NaO}_{2} \text { ) }\end{array}$} & \multicolumn{2}{|c|}{$\begin{array}{l}\text { R3 (without } \\
\text { COD) }\end{array}$} \\
\hline & Description of Activities & 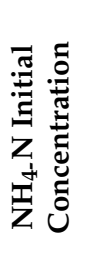 & 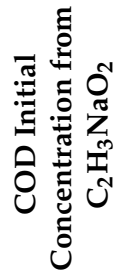 & & 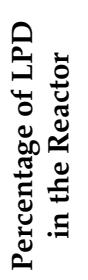 & 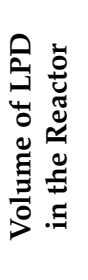 & 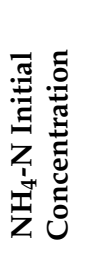 & 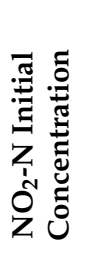 & 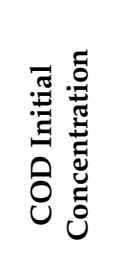 & 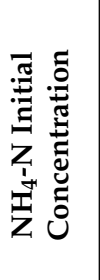 & 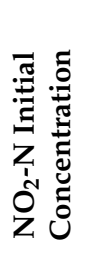 & 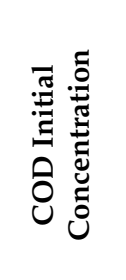 & 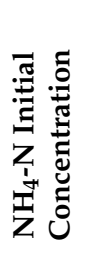 & 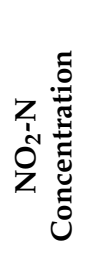 \\
\hline & - & $\frac{\mathrm{mg} \mathrm{N}}{\mathrm{dm}^{3}}$ & $\frac{\mathrm{mg} \text { COD }}{\mathrm{dm}^{3}}$ & - & $\%$ & $\mathrm{dm}^{3}$ & $\frac{\mathrm{mg} \mathrm{N}}{\mathrm{dm}^{3}}$ & $\frac{\mathrm{mg} \mathrm{N}}{\mathrm{dm}^{3}}$ & $\frac{\mathrm{mg} \text { COD }}{\mathrm{dm}^{3}}$ & $\frac{\mathrm{mg} \mathrm{N}}{\mathrm{dm}^{3}}$ & $\frac{\mathrm{mg} \mathrm{N}}{\mathrm{dm}^{3}}$ & $\frac{\mathrm{mg} \text { COD }}{\mathrm{dm}^{3}}$ & $\frac{\mathrm{mg} \mathrm{N}}{\mathrm{dm}^{3}}$ & $\frac{\mathrm{mg} \mathrm{N}}{\mathrm{dm}^{3}}$ \\
\hline $0-90$ & Adaptation for the deammonification process & 40 & 0 & \multicolumn{11}{|c|}{ No research } \\
\hline 91 & \multicolumn{3}{|l|}{ No research } & Test 1 & 0.5 & 0.15 & 10 & 13 & 22 & 10 & 13 & 22 & 10 & 13 \\
\hline 92-106 & Adaptation for the deammonification process & 30 & 30 & \multicolumn{11}{|c|}{ No research } \\
\hline 107 & \multicolumn{3}{|l|}{ No research } & Test 2 & 1 & 0.03 & 20 & 26 & 45 & 20 & 26 & 45 & 20 & 26 \\
\hline $108-122$ & Adaptation for the deammonification process & 45 & 45 & \multicolumn{11}{|c|}{ No research } \\
\hline 123 & \multicolumn{3}{|l|}{ No research } & Test 3 & 2 & 0.06 & 40 & 52 & 90 & 40 & 52 & 90 & 40 & 52 \\
\hline $124-136$ & Adaptation for the deammonification process & 90 & 90 & \multicolumn{11}{|c|}{ No research } \\
\hline 137 & \multicolumn{3}{|l|}{ No research } & Test 4 & 3 & 0.09 & 60 & 78 & 138 & 60 & 78 & 138 & 60 & 78 \\
\hline $138-152$ & Adaptation for the deammonification process & 138 & 138 & \multicolumn{11}{|c|}{ No research } \\
\hline 153 & \multicolumn{3}{|l|}{ No research } & Test 5 & 4 & 0.12 & 80 & 104 & 180 & 80 & 104 & 180 & 80 & 104 \\
\hline $154-168$ & Adaptation for the deammonification process & 180 & 180 & \multicolumn{11}{|c|}{ No research } \\
\hline 169 & \multicolumn{3}{|l|}{ No research } & Test 6 & 5 & 0.6 & 100 & 130 & 225 & 100 & 130 & 225 & 100 & 130 \\
\hline 169-183 & Adaptation for the deammonification process & 225 & 225 & \multicolumn{11}{|c|}{ No research } \\
\hline 184 & No research & & & Test 7 & 7.5 & 0.225 & 145 & 190 & 337.5 & 150 & 195 & 337.5 & 150 & 195 \\
\hline
\end{tabular}


(b) The Batch Reactors in the Anammox Mode

Three batch reactors (R1, R2, R3) worked in anammox mode. Sludge was collected from the main SBR reactor for each test and divided into three batch reactors. Synthetic wastewater was used to supply each batch reactor prepared according to Dapena-Mora et al. [22], but with the addition of COD from LPD (R1) and $\mathrm{C}_{2} \mathrm{H}_{3} \mathrm{NaO}_{2}$ (R2). Temperature and $\mathrm{pH}$ were not controlled. An increasingly greater proportion of the LPD was added to R1 in 7 tests according to Table 1. COD in the form of $\mathrm{C}_{2} \mathrm{H}_{3} \mathrm{NaO}_{2}$ was added to $\mathrm{R} 2$ at the same concentration as in $\mathrm{R} 1$, to compare the different COD sources in the reactors and study the effect of the unknown compounds in the effluents in R1. Both R1 and $\mathrm{R} 2$ were maintained at a $\mathrm{C} / \mathrm{N}$ ratio of 1 throughout the test period. $\mathrm{NO}_{2}-\mathrm{N}$ was added to each of the reactor batch in a precise amount so as to meet the optimal conditions for the anammox process (ratio 1:3 $\mathrm{NO}_{2}-\mathrm{N} / \mathrm{NH}_{4}-\mathrm{N}$ ). The same concentration of $\mathrm{NH}_{4}-\mathrm{N}$ and $\mathrm{NO}_{2}-\mathrm{N}$ was maintained in $\mathrm{R} 3$ as in R1 and R2, without the addition of COD, in order to check the effect of COD on the anammox process. The $\mathrm{NH}_{4}-\mathrm{N}, \mathrm{NO}_{2}-\mathrm{N}$ and COD concentrations at the beginning of each test are shown in Table 1.

\subsection{Characteristics of the Digestate}

The digestate was obtained during the tests of the methane co-fermentation process carried out on a laboratory scale in reactors with a volume of $44 \mathrm{~L}$. Reactors operated in batch mode. The initial feed was $20 \%$ inoculum, in the form of sludge, from the municipal sewage treatment plant fermentation chambers in Warsaw (Poland) and $80 \%$ substrate. In the analyzed studies, the substrate included waste activated sludge from the municipal sewage treatment plant in Warsaw and cattle slurry in the proportion of 1:3 (as wet mass of substrates). During the first two days, the feed hydrolysis was carried out at a temperature of approximately $30^{\circ} \mathrm{C}$. Then, for 28 days, the main fermentation process was carried out at a temperature of about $38{ }^{\circ} \mathrm{C}$. The initial $\mathrm{pH}$ in the fermentor was adjusted to approximately $\mathrm{pH}$ 7. A more detailed description of the fermentation was presented in the previous publication [23].

After the fermentation process was completed, the digestate was separated into a solid and liquid fraction using a Jouan C3i laboratory centrifuge. A centrifugation speed of $4000 \mathrm{rpm}$, characteristic for the operation of industrial centrifuges, was adopted. The spin time was $30 \mathrm{~min}$. The liquid fraction was then filtered through a $0.45 \mu \mathrm{m}$ filter to separate the slurry fraction. Liquid fraction of digestates containing pollutants only, in the form of dissolved fractions, were used for the tests. The characteristics of the digestate and LPD are presented in Table 2. A detailed analysis of the nitrogen and phosphorus content in the liquid fraction of the digestate was presented in a previous publication [23].

Table 2. Characteristics of the digestate and LPD.

\begin{tabular}{|c|c|c|c|}
\hline Compound & Unit & $\begin{array}{l}\text { Concentration } \\
\text { in the Digestate }\end{array}$ & $\begin{array}{l}\text { Concentration } \\
\text { in the LPD (SD) }\end{array}$ \\
\hline $\mathrm{TN}$ & $\mathrm{mg} \mathrm{N} / \mathrm{dm}^{3}$ & 3121 & $2627.7(255.2)$ \\
\hline $\mathrm{TN}_{\mathrm{f}}$ & $\mathrm{mg} \mathrm{N} / \mathrm{dm}^{3}$ & n.a. & $1788.2(113.8)$ \\
\hline COD & $\mathrm{mg} \mathrm{O}_{2} / \mathrm{dm}^{3}$ & 36400 & 7650 (739.9) \\
\hline $\mathrm{COD}_{\mathrm{f}}$ & $\mathrm{mg} \mathrm{O}_{2} / \mathrm{dm}^{3}$ & n.a. & 2590 (197.5) \\
\hline $\mathrm{NH}_{4}-\mathrm{N}$ & $\mathrm{mg} \mathrm{N} / \mathrm{dm}^{3}$ & n.a. & $1546.7(36.9)$ \\
\hline $\mathrm{TP}$ & $\mathrm{mg} \mathrm{P} / \mathrm{dm}^{3}$ & 1075 & n.a. \\
\hline $\mathrm{N}_{\text {org }}$ & $\mathrm{mg} \mathrm{N} / \mathrm{dm}^{3}$ & n.a. & $1081(223.3)$ \\
\hline $\mathrm{N}_{\text {orgf }}$ & $\mathrm{mg} \mathrm{N} / \mathrm{dm}^{3}$ & n.a. & $241.5(80.5)$ \\
\hline TSS & $\%$ & 4.13 & n.a. \\
\hline VSS & $\%$ & 53.27 & n.a. \\
\hline
\end{tabular}

$\mathrm{TN}$-total nitrogen without filtration, $\mathrm{TN}_{\mathrm{f}}$-total nitrogen after filtration, COD-chemical oxygen demand without filtration, $\mathrm{COD}_{\mathrm{f}}$-chemical oxygen demand with filtration, TP-total phosphorus, $\mathrm{N}_{\text {org }}$-organic nitrogen without filtration, $\mathrm{N}_{\text {orgf }}$-organic nitrogen with filtration, TSS-total suspended solids, VSS- volatile suspended solids, SD-standard deviation, n.a.-not applicable. 


\subsection{Analytical Methods}

The concentration of $\mathrm{COD}, \mathrm{NO}_{3}-\mathrm{N}, \mathrm{NO}_{2}-\mathrm{N}, \mathrm{NH}_{4}-\mathrm{N}$ compounds were determined using a spectrophotometer, DR 3900 using cuvette tests from Hach Lange GmbH (Dusseldorf, Germany) for this type of analysis. High-temperature mineralizer was used for COD analysis. The device was equipped with twelve pockets for tested samples. It reached a maximum operating temperature of $170^{\circ} \mathrm{C}$ and the complete cooling time of the test sample was about $40-45 \mathrm{~min}$.

The biomass concentrations, were determined as a volatile suspended solids (VSS) fraction of the total suspended solids (TSS) in accordance to Standard Methods [24]. The biomass specific ammonium utilization rate (AUR), specific anammox activity (SAA), and nitrate production rate (NPR) were determined based on the maximum slope of $\mathrm{NH}_{4}-\mathrm{N}$ consumption, $\mathrm{NH}_{4}-\mathrm{N}$ together with $\mathrm{NO}_{2}-\mathrm{N}$ consumption, and $\mathrm{NO}_{3}-\mathrm{N}$ production in the reaction phase divided into MLVSS concentration, respectively.

\section{Results and Discussion}

During the tests, an increase in the speed of the AUR and SAA processes were observed in all batch reactors, as shown in Figure 2a,b. Miao et al. [25] also reported in their research that the activity of anammox increased with an increase in the $\mathrm{C} / \mathrm{N}$ ratio. As the $\mathrm{C} / \mathrm{N}$ ratio increased from 1.1 to 2, the improvement in nitrogen removal was attributed to increased AAOB counts.

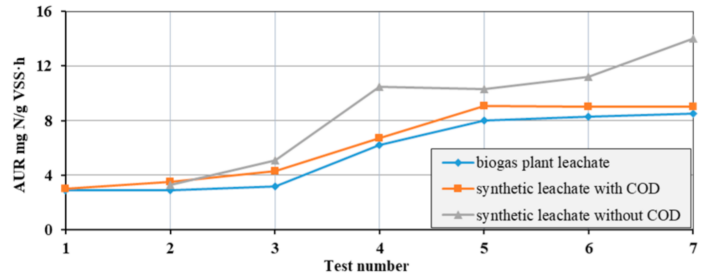

(a)

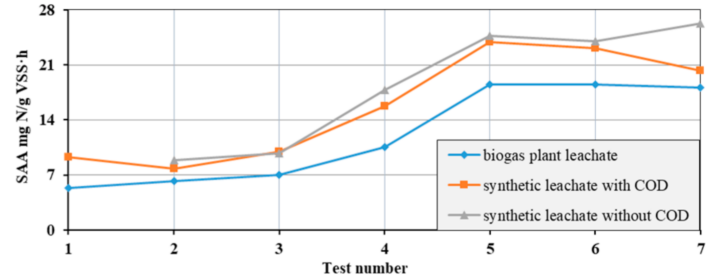

(b)

Figure 2. Values of (a) AUR (b) SAA for anammox process carried out with LPD addition, with synthetic effluents with COD and with synthetic effluents without COD.

The AUR value in the R1 increased from $2.3 \mathrm{mg} \mathrm{N} /(\mathrm{g}$ VSS.h) in the $1 \mathrm{st}$ test to $8.5 \mathrm{mg} \mathrm{N} /(\mathrm{g}$ VSS.h) in the 7th test. However, this ratio was the lowest when compared to R2 and R3. In R2, this rate increased from $3 \mathrm{mg} \mathrm{N} /(\mathrm{g}$ VSS$\cdot h)$ in the 1st test to $9 \mathrm{mg} \mathrm{N} /(\mathrm{g}$ VSS$\cdot h$ ) in the 7th test. On the other hand, in R3, AUR increased from $3.3 \mathrm{mg} \mathrm{N} /(\mathrm{g}$ VSS.h) in the 2nd test to $14 \mathrm{mg} \mathrm{N} /(\mathrm{g}$ VSS.h) in the 7th test.

Figure $2 b$ shows that in R3-SAA increased. This was due to the adaptation of AAOB and the fact that AAOB prefer high concentrations of NH4-N, and its concentration increased in subsequent tests (NH4-N was added in each reactor with the same concentration to keep $\mathrm{C} / \mathrm{N}=1$ with increasing COD concentration, NH4-N concentration in the reactor increased). In R1 and R2 with COD in 5\%, SAA was stabilized, which was probably due to the growing share of organic compounds in COD.

SAA in R1 increased from $5.3 \mathrm{mg} \mathrm{N} /(\mathrm{g}$ VSS.h) in the 1 st test to $18.5 \mathrm{mg} \mathrm{N} /(\mathrm{g}$ VSS.h) in the 5 th and 6th tests. In the 7th test, the SAA dropped to the value of $18.1 \mathrm{mg} \mathrm{N} /(\mathrm{g}$ VSS.h).

In the R2, SAA increased from $7.8 \mathrm{mg} \mathrm{N} /(\mathrm{g}$ VSS.h) in the 2 nd test to $23.9 \mathrm{mg} \mathrm{N} /(\mathrm{g} \mathrm{VSS} \cdot \mathrm{h})$ in the 5 th test. The SAA then decreased to $20.3 \mathrm{mg} \mathrm{N} /(\mathrm{g}$ VSS.h) in the 7th test.

The literature reports that high concentrations of COD suppresses anammox activity and that concentrations of COD up to $297 \mathrm{mg} / \mathrm{dm}^{3}$ can completely inhibit AAOB [26]. In our study, despite the addition of COD $329 \mathrm{mg} / \mathrm{dm}^{3}$ in the 7th test, there was no inhibition of AAOB due to the C/N ratio being equal to 1 . On the other hand, the addition of acetate can be used by AAOB to remove $\mathrm{NO}_{3}-\mathrm{N}$ [27].

In R3, SAA increased from the value of $8.9 \mathrm{mg} \mathrm{N} /(\mathrm{g}$ VSS.h) in the 2nd test, while in the 7th test it was the highest and amounted to $26.3 \mathrm{mg} \mathrm{N} /(\mathrm{g}$ VSS$\cdot h)$. 
In reactors with effluents containing organic compounds expressed in COD (both LPD and acetates), the SAA reached its maximum value in the 5th test. The higher the COD concentration, the more SAA decreased. On the other hand, in R3, SAA continued to grow.

Therefore, it can be seen that COD has a negative effect on the anammox process. Due to the similar trend in both R1 and R2, it can be concluded that the effect on SAA reduction is mainly due to the presence of COD.

This is also confirmed in the literature, which states that high concentrations of COD inhibit the activity of anammox, which could be caused by two potential pathways [12]. The first is "inhibition of competition" and the second is "inhibition of the conversion of the metabolic pathway" [28]. The first relates to competition of heterotrophic bacteria with $\mathrm{AAOB}$ for nutrients at high concentrations of $\mathrm{COD}$, however heterotrophic bacteria grow faster than $\mathrm{AAOB}$, as a result the proportion of $\mathrm{AAOB}$ is reduced or completely eliminated, which reduced their activity [29]. However, the anammox process restricted at high COD concentrations due to the growth of heterotrophic bacteria is reversible [30]. The second route focuses on dominant AAOBs that metabolize to organic carbon instead of $\mathrm{NH}_{4}-\mathrm{N}$ and $\mathrm{NO}_{2}-\mathrm{N}$, leading to lower activity and reduced nitrogen removal efficiency [31].

Molinuevo et al. [26] report that $\mathrm{AAOB}$ compete with denitrifying bacteria when the $\mathrm{C} / \mathrm{N}$ ratio $>1$. $\mathrm{AAOB}$ can survive in laboratory reactors and wastewater treatment plants when the $\mathrm{C} / \mathrm{N}$ ranges from $0.5-2.8$ [32-34], with varying $\mathrm{NH}_{4}-\mathrm{N}$ removal efficiency (50-96\%). Other sources say that at a $\mathrm{C} / \mathrm{N}$ ratio of $0.5-0.8$, the medium is dominated by autotrophic microorganisms $[35,36]$, while at a $\mathrm{C} / \mathrm{N}$ ratio in the range of 1-1.4 anammox and denitrification occur simultaneously, which is indicated for simultaneous anammox and denitrification (SAD) [37]. Based on the above reports, our $\mathrm{C} / \mathrm{N}$ ratio of 1 seems to be appropriate for the anammox process.

NPR in all batch reactors were the highest on the first days of the research (see Figure 3a). This is due to the fact that such low concentrations of $\mathrm{NH}_{4}-\mathrm{N}$ and $\mathrm{NO}_{2}-\mathrm{N}$ meant that the majority of processes occurred with full nitrification. This situation is also confirmed by the fact that with the addition of 0.5 and $1 \%$ LPD, the highest ratio of NPR/AUR was achieved (see: Figure $3 b$ ).

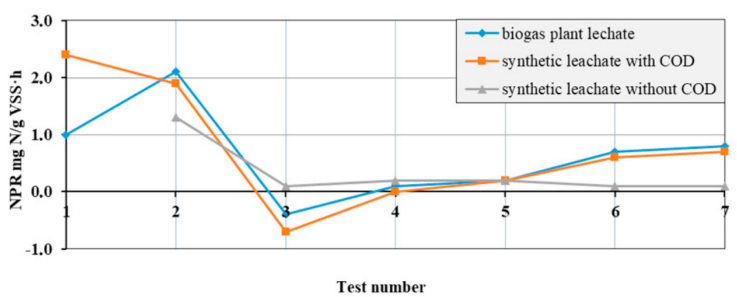

(a)

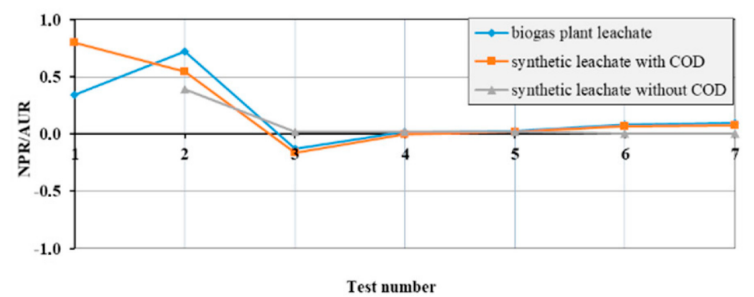

(b)

Figure 3. Values of (a) NPR (b) NPR/AUR for anammox process carried out with LPD addition, with synthetic effluents with COD and with synthetic effluents without COD.

In the 3rd test it can be seen that the NPR has dropped below 0 . This may possibly be due to the use of COD compounds for denitritation. The concentration of COD compounds was so low that they did not interfere with nitrification or anammox, but also allowed the reduction of $\mathrm{NO}_{3}-\mathrm{N}$. Compounds in synthetic effluents are the most bioavailable for denitrification and were the preferred carbon source because NPR was the lowest and the highest reduction in $\mathrm{NO}_{3}-\mathrm{N}$ concentration.

On the other hand, above 5\% LPD in the reactor, it can also be seen that the NPR is higher (i.e., the greater part of the compounds are oxidized by the bacteria of the second nitrification phase- $-\mathrm{NOB}$ ) - the production of $\mathrm{NO}_{3}-\mathrm{N}$ confirms this. Moreover, above $5 \%$ LPD in R1 and R2, the $\mathrm{NO}_{2}-\mathrm{N} / \mathrm{NH}_{4}-\mathrm{N}$ ratio increases during the test and it confirms the theory that part of $\mathrm{NH}_{4}-\mathrm{N}$ oxidation is caused by $\mathrm{NOB}$ bacteria $\left(\mathrm{NO}_{2}-\mathrm{N}\right.$ does not decrease slower), in other words adding $\mathrm{COD}$ reduces the SAA. 
Table S1 (Supplementary Data) summarizes the AUR, NPR, SAA rates and the NPR/AUR ratio achieved.

It is also worth paying attention to the time needed for the complete oxidation of $\mathrm{NH}_{4}-\mathrm{N}$ in $\mathrm{R} 1$. When the LPD addition was $1 \%, \mathrm{NH}_{4}-\mathrm{N}$ was completely oxidized in $1.5 \mathrm{~h}$. When the LPD addition was $3 \%, \mathrm{NH}_{4}-\mathrm{N}$ was completely oxidized in $3 \mathrm{~h}$, and when the LPD addition was $7.5 \%, \mathrm{NH}_{4}-\mathrm{N}$ was completely oxidized in $6 \mathrm{~h}$. Thus, it turns out that the reaction time increases with the increase in proportion of digestate added (see Figure 4a). This is also indicated by the decrease in $\mathrm{NO}_{2}-\mathrm{N}$ concentration in individual cases (see Figure $4 \mathrm{~b}$ ) and is due to the increased amount of $\mathrm{NH}_{4}-\mathrm{N}$ needed to be oxidized.

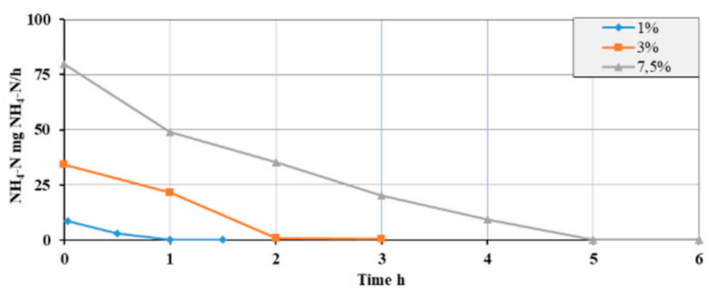

(a)

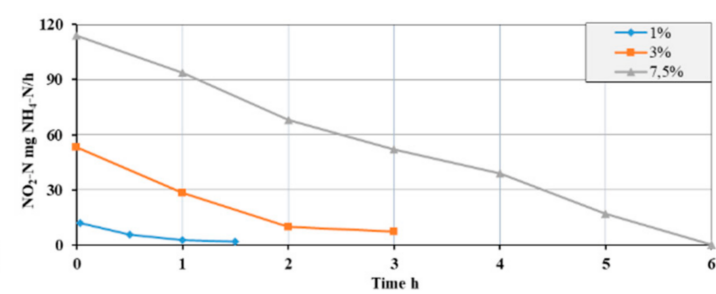

(b)

Figure 4. Concentration values of (a) $\mathrm{NH}_{4}-\mathrm{N}(\mathbf{b}) \mathrm{NO}_{2}-\mathrm{N}$ for the process carried out with $1 \%, 3 \%$ and $7.5 \%$ digestate leachate.

\section{Conclusions}

The conducted experiments revealed the potential of LPD purification, which co-ferments waste activated sludge and bovine slurry for the anammox process. AUR and SAA increase in subsequent tests for each of the three reactors, but the most favorable values were obtained for R3, which indicates that COD does not cause competition of heterotrophic bacteria for $\mathrm{NO}_{2}-\mathrm{N}$, as is the case in $\mathrm{R} 1$ and $\mathrm{R} 2$. The AUR in R1 is lower than in R2 due to the possible presence of inhibitory substances contained in LPD, which are not well understood at the moment. Future research is planned to identify them. The addition of COD resulted in a negative NPR value with an initial COD concentration of $90 \mathrm{mg}$ $\mathrm{COD} / \mathrm{dm}^{3}$, which indicates heterotrophic denitrification in this period. The increase in NPR value in subsequent tests at higher substrate concentrations proves the advantage of AAOB over denitrifying bacteria. It was indicated in the study that the increased proportion of LPD in the anammox process also extended the time needed to oxidize $\mathrm{NH}_{4}-\mathrm{N}$.

Supplementary Materials: The following are available online at http://www.mdpi.com/2073-4441/12/11/2965/s1, Table S1: AUR, NPR, SAA rates and the NPR/AUR ratio achieved.

Author Contributions: Conceptualization, D.G. and J.M.; methodology, J.M. and K.C.; software, J.M.; validation, K.C.; formal analysis, K.C.; investigation, D.G. and J.M.; resources, K.C.; data curation, J.M.; writing-original draft preparation, D.G. and J.M.; writing—review and editing, K.C.; visualization, D.G.; supervision, K.C.; project administration, D.G.; funding acquisition, K.C. All authors have read and agreed to the published version of the manuscript.

Funding: This research was funded by European Regional Development Fund within the framework of Smart Growth Operational Programme 2014-2020 grant number POIR.04.01.02-00-0022/17.

Conflicts of Interest: The authors declare no conflict of interest.

\section{References}

1. Liu, X.; Wang, H.; Li, H.; Jin, Y.; Zhang, W. Carbon sequestration pathway of inorganic carbon in partial nitrification sludge. Bioresour. Technol. 2019, 293, 122101. [CrossRef]

2. Azari, M.; Walter, U.; Rekers, V.; Gu, J.; Denecke, M. More than a decade of experience of landfill leachate treatment with a full-scale anammox plant combining activated sludge and activated carbon biofilm. Chemosphere 2017, 174, 117-126. [CrossRef] 
3. Wang, X.; Yang, R.; Zhang, Z.; Wu, J.; Chen, S. Mass balance and bacterial characteristics in an in-situ full-scale swine wastewater treatment system occurring anammox process. Bioresour. Technol. 2019, 292, 122005. [CrossRef]

4. Chen, H.; Liu, S.; Yang, F.; Xue, Y.; Wang, T. The development of simultaneous partial nitrification, ANAMMOX and denitrification (SNAD) process in a single reactor for nitrogen removal. Bioresour. Technol. 2009, 100, 1548-1554. [CrossRef] [PubMed]

5. Cao, S.; Wang, S.; Peng, Y.; Wu, C.; Du, R.; Gong, L.; Ma, B. Achieving partial denitrification with sludge fermentation liquid as carbon source: The effect of seeding sludge. Bioresour. Technol. 2013, 149, 570-574. [CrossRef] [PubMed]

6. Du, R.; Peng, Y.; Cao, S.; Wang, S.; Wu, C. Advanced nitrogen removal from wastewater by combining anammox with partial denitrification. Bioresour. Technol. 2015, 179, 497-504. [CrossRef] [PubMed]

7. Kuenen, J.G. Anammox bacteria: From discovery to application. Nat. Rev. Microbiol. 2008, 6, 320-326. [CrossRef] [PubMed]

8. Pijuan, M.; Ribera-Guardia, A.; Balcázar, J.L.; Micó, M.M.; de la Torre, T. Effect of COD on mainstream anammox: Evaluation of process performance, granule morphology and nitrous oxide production. Sci. Total Environ. 2020, 712, 136372. [CrossRef]

9. Qin, Y.; Cao, Y.; Ren, J.; Wang, T.; Han, B. Effect of glucose on nitrogen removal and microbial community in anammox-denitrification system. Bioresour. Technol. 2017, 244, 33-39. [CrossRef]

10. Chen, C.; Sun, F.; Zhang, H.; Wang, J.; Shen, Y.; Liang, X. Evaluation of COD effect on anammox process and microbial communities in the anaerobic baffled reactor (ABR). Bioresour. Technol. 2016, 216, 571-578. [CrossRef] [PubMed]

11. Chen, C.; Zhang, M.; Yu, X.; Mei, J.; Jiang, Y.; Wang, Y.; Zhang, T.C. Effect of C/N ratios on nitrogen removal and microbial communities in the anaerobic baffled reactor (ABR) with an anammox-coupling-denitrification process. Water Sci. Technol. 2018, 78, 2338-2348. [CrossRef] [PubMed]

12. Sheng, S.; Liu, B.; Hou, X.; Liang, Z.; Sun, X.; Du, L.; Wang, D. Effects of different carbon sources and C/N ratios on the simultaneous anammox and denitrification process. Int. Biodeterior. Biodegrad. 2018, 127, $26-34$. [CrossRef]

13. Bi, Z.; Takekawa, M.; Park, G.; Soda, S.; Qiao, S.; Ike, M. Effects of the C/N ratio and bacterial populations on nitrogen removal in the simultaneous anammox and heterotrophic denitrification process: Mathematic modeling and batch experiments. Chem. Eng. J. 2015, 280, 606-613. [CrossRef]

14. Nkoa, R. Agricultural benefits and environmental risks of soil fertilization with anaerobic digestates: A review. Agron. Sustain. Dev. 2014, 34, 473-492. [CrossRef]

15. Monfet, E.; Aubry, G.; Ramirez, A.A. Nutrient removal and recovery from digestate: A review of the technology. Biofuels 2018, 9, 247-262. [CrossRef]

16. Vaneeckhaute, C.; Lebuf, V.; Michels, E.; Belia, E.; Vanrolleghem, P.A.; Tack, F.M.G.; Meers, E. Nutrient Recovery from Digestate: Systematic Technology Review and Product Classification. Waste Biomass Valorization 2017, 8, 21-40. [CrossRef]

17. Bolzonella, D.; Fatone, F.; Gottardo, M.; Frison, N. Nutrients recovery from anaerobic digestate of agro-waste: Techno-economic assessment of full scale applications. J. Environ. Manag. 2018, 216, 111-119. [CrossRef]

18. Shi, L.; Simplicio, W.S.; Wu, G.; Hu, Z.; Hu, H.; Zhan, X. Nutrient Recovery from Digestate of Anaerobic Digestion of Livestock Manure: A Review. Curr. Pollut. Rep. 2018, 4, 74-83. [CrossRef]

19. European Commission. Council Directive of 12 December 1991 Concerning the Protection of Waters against Pollution Caused by Nitrates from Agricultural Sources; 91/676/EEC; European Commission: Brussels, Belgium, 1991; pp. 3-7.

20. Al Seadi, T.; Drosg, B.; Fuchs, W.; Rutz, D.; Janssen, R. Biogas digestate quality and utilization. In The Biogas Handbook: Science, Production and Applications; University of Southern Denmark Esbjerg: Esbjerg, Denmark, 2008; pp. 267-301. ISBN 978-87-992962-0-0.

21. Majtacz, J.; Dominika, G.; Kowal, P.; Czerwionka, K. Possibilities of leachate co-treatment originating from biogas production in the deammonification process. J. Ecol. Eng. 2020, 21, 14-19. [CrossRef]

22. Dapena-Mora, A.; Arrojo, B.; Campos, J.L.; Mosquera-Corral, A.; Méndez, R. Improvement of the settling properties of Anammox sludge in an SBR. J. Chem. Technol. Biotechnol. 2004, 79, 1417-1420. [CrossRef]

23. Tuszynska, A.; Wilinska, A.; Czerwionka, K. Phosphorus and nitrogen forms in liquid fraction of digestates from agricultural biogas plants. Environ. Technol. 2020, 1-13. [CrossRef] 
24. Greenberg, A.E.; Clesceri, L.S.; Eaton, A.D. APHA Standard Methods for the Examination of Water and Waste Water, 21st ed.; American Public Health Association: Washington, DC, USA; American Water Works Association: Washington, DC, USA; Water Pollution Control Federation: Washington, DC, USA, 2005.

25. Miao, Y.; Peng, Y.; Zhang, L.; Li, B.; Li, X.; Wu, L.; Wang, S. Partial nitrification-anammox (PNA) treating sewage with intermittent aeration mode: Effect of influent $\mathrm{C} / \mathrm{N}$ ratios. Chem. Eng. J. 2018, 334, 664-672. [CrossRef]

26. Molinuevo, B.; García, M.C.; Karakashev, D.; Angelidaki, I. Anammox for ammonia removal from pig manure effluents: Effect of organic matter content on process performance. Bioresour. Technol. 2009, 100, 2171-2175. [CrossRef] [PubMed]

27. Jenni, S.; Vlaeminck, S.E.; Morgenroth, E.; Udert, K.M. Successful application of nitritation/anammox towastewater with elevated organic carbon to ammonia ratios. Water Res. 2014, 49, 316-326. [CrossRef]

28. Jin, R.C.; Yang, G.F.; Yu, J.J.; Zheng, P. The inhibition of the Anammox process: A review. Chem. Eng. J. 2012, 197, 67-79. [CrossRef]

29. Chamchoi, N.; Nitisoravut, S.; Schmidt, J.E. Inactivation of ANAMMOX communities under concurrent operation of anaerobic ammonium oxidation (ANAMMOX) and denitrification. Bioresour. Technol. 2008, 99, 3331-3336. [CrossRef]

30. Zekker, I.; Raudkivi, M.; Artemchuk, O.; Rikmann, E.; Priks, H.; Jaagura, M.; Tenno, T. Mainstream-sidestream wastewater switching promotes anammox nitrogen removal rate in organic-rich, low-temperature streams. Environ. Technol. 2020, 1-10. [CrossRef]

31. Kartal, B.; Van Niftrik, L.; Rattray, J.; Van De Vossenberg, J.L.C.M.; Schmid, M.C.; Sinninghe Damsté, J.; Jetten, M.S.M.; Strous, M. Candidatus 'Brocadia fulgida': An autofluorescent anaerobic ammonium oxidizing bacterium. FEMS Microbiol. Ecol. 2008, 63, 46-55. [CrossRef]

32. Suto, R.; Ishimoto, C.; Chikyu, M.; Aihara, Y.; Matsumoto, T.; Uenishi, H.; Yasuda, T.; Fukumoto, Y.; Waki, M. Anammox biofilm in activated sludge swine wastewater treatment plants. Chemosphere 2017, 167, 300-307. [CrossRef]

33. Daverey, A.; Hung, N.T.; Dutta, K.; Lin, J.G. Ambient temperature SNAD process treating anaerobic digester liquor of swine wastewater. Bioresour. Technol. 2013, 141, 191-198. [CrossRef]

34. Zhang, Z.; Li, Y.; Chen, S.; Wang, S.; Bao, X. Simultaneous nitrogen and carbon removal from swine digester liquor by the Canon process and denitrification. Bioresour. Technol. 2012, 114, 84-89. [CrossRef] [PubMed]

35. Zekker, I.; Rikmann, E.; Kroon, K.; Mandel, A.; Mihkelson, J.; Tenno, T.; Tenno, T. Ameliorating nitrite inhibition in a low-temperature nitritation-anammox MBBR using bacterial intermediate nitric oxide. Int. J. Environ. Sci. Technol. 2017, 14, 2343-2356. [CrossRef]

36. Lotti, T.; Kleerebezem, R.; Hu, Z.; Kartal, B.; De Kreuk, M.K.; Van Erp Taalman Kip, C.; Kruit, J.; Hendrickx, T.L.G.; van Loosdrecht, M.C.M. Pilot-scale evaluation of anammox-based mainstream nitrogen removal from municipal wastewater. Environ. Technol. 2015, 36, 1167-1177. [CrossRef] [PubMed]

37. Jalilzadeh, A.; Nabizadeh, R.; Mesdaghinia, A.; Azimi, A.; Nasseri, S.; Mahvi, A.H.; Naddafi, K. Optimization and modelling of chemical oxygen demand removal by ANAMMOX process using response surface methodology. J. Chem. 2013, 1-8. [CrossRef]

Publisher's Note: MDPI stays neutral with regard to jurisdictional claims in published maps and institutional affiliations.

(C) 2020 by the authors. Licensee MDPI, Basel, Switzerland. This article is an open access article distributed under the terms and conditions of the Creative Commons Attribution (CC BY) license (http://creativecommons.org/licenses/by/4.0/). 